\title{
Study of Bridge Damages on Local Roads in Latvia
}

\author{
Roberts Auzins*, Ainars Paeglitis \\ Department of Roads and Bridges, Civil Engineering Faculty, Riga Technical University, Riga, Latvia
}

Received 4 February 2020; accepted 31 March 2020

\begin{abstract}
Local roads (V class roads) and the bridges on them compose a significant part of the public road network in Latvia. On local roads are around $45 \%$ of all bridges located on the national road network. These are mostly reinforced concrete bridges with short or middle span lengths, with one or two traffic lines. Due to low traffic flow, these structures are used lover maintenance classes. The lover maintenance class also includes less de-icing salt in winter maintenance and less founds for maintenance works. At the same time, some of these bridges are located on routes used by heavy timber trucks or trucks taking sand from quarries. Also, agricultural machinery and local people cars are using these bridges for everyday needs. Therefore, the safe exploitation of these structures is essential. Due to different service conditions, the development of deteriorations also will be different. This paper aims to study the development of characteristic types of damages, its causes and consequences and impact on structural performance and service life.
\end{abstract}

Keywords: bridge, bridge stock, inventory, inspection, maintenance, condition, load model.

\section{Introduction}

Bridges are the most vulnerable part of the road infrastructure network. They are subjected to the aggressive environment - frequent use of de-icing salt, many freeze-thaw cycles in wintertime, high relative humidity, etc., as well the increasing heavy transport traffic flow. Also, it could be considered the ageing of existing bridge stock and increase of necessary financial funds for maintenance works. The right management of all these aspects plays an essential role for ensuring the functionality, availability and capacity of bridge stock (Quirk et al., 2018; Mondoro et al., 2018). Development of bridge management systems (BMS) will help authorities planning necessary maintenance, repair, rehabilitation and interventions works in a systematic way, optimizing the allocation of financial resources and increasing the safety of bridge users (Ryall, 2006).

The safety of bridge users is a crucially important factor for society. The bridge management systems have existed in Latvia since the beginning of the last century in one or another way. Till 1940 it was random inspections after floods or other natural or damages. Each bridge had a passport with general information about location, dimensions and materials. According to regulation (Rīkojums Nr.C/55 Par tiltu uzturēšanu un remontiem, 1938) bridges were inspected if there was observed some damages or problems. The decisions for interventions were taken in tree levels depending on the amount of the proposed cost of repair works. From 1945 till 1991 the bridge management was carried out according to that time regulations (VSN-81, 1981; SNiP, 1987) that provide bridge inventory card and two-step inspections: regular - yearly and special inspection every ten years with an assessment of the technical condition and evaluation of load-carrying capacity. From 1995 was introduced a simplified computer-based Bridge inventory and inspection form, as well as, determining types of inspection and their regularity. In 2002 in cooperation with Norwegian Road Administration was designed and introduced a computerized Bridge management system LatBrutus (Stensvold, 1997).

On local roads are around $45 \%$ of all bridges located on the national road network. A developed and wellmaintained local road network plays an essential role in ensuring the Latvian economy. However, the maintenance of these roads is not sufficiently attentive. Due to different service conditions, the development of deteriorations also will be different. This paper aims to study the development of characteristic types of damages, its causes and consequences and impact on structural performance and service life.

\footnotetext{
${ }^{*}$ Corresponding author. E-mail: roberts.auzins@rtu.lv
} 


\section{Bridge stock in general}

There are more than 70 thousand kilometres of roads in Latvia. SJSC "Latvian State Roads" are managing more than 20 thousand of them. Latvian State roads are divided into three large groups - main roads (A), regional roads (P) and local roads $(\mathrm{V})$. Although local roads are strategically least important, they are more than half (almost 13 thousand kilometres) of overall Latvian State road network. Main characteristics of typical Latvian local roads are unpaved cover, low traffic intensity (weighted average intensity is 262 cars in a day), poorly maintained.

From 971 bridges managed by Latvian State Rods $44 \%$ or 431 of them are on local roads. As they are the least maintained constructions, the technical condition of these bridges is poor. As can be seen in Figure 1, almost two thirds $(62 \%)$ of bridges on local roads are in poor or very poor technical condition. It is very significant to get and analyze collected bridge inspection and damage data to be able to make the right decisions in bridge management scope.

\section{Bridge condition (all 431 bridge on local roads)}

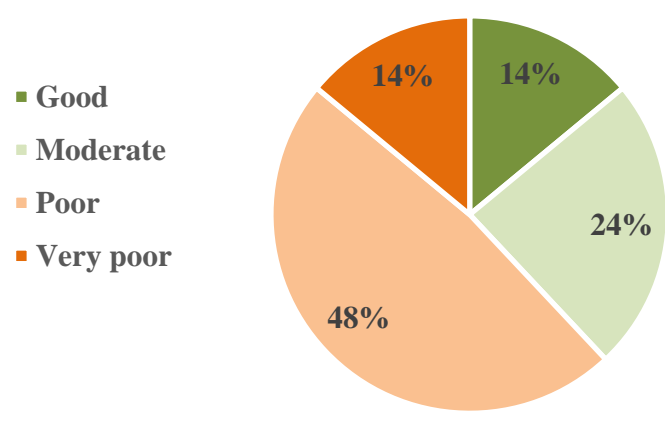

\author{
Bridge condition \\ (data set from 301 bridge)
}

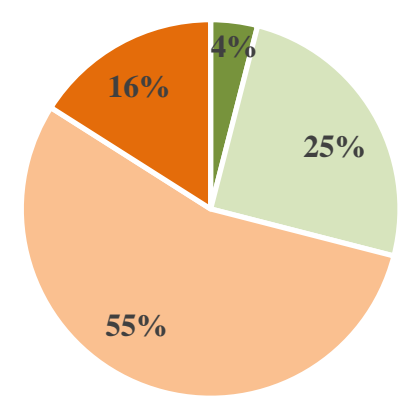

Figure 1. Technical condition of local road bridges

\subsection{Bridge stock on local roads}

The purpose of this study is to analyze data about the damages of the existing bridges of the local road network. In this study are analyzed data of 301 bridges (total number of bridges on local Latvian roads is 431). The set of analyzed data consists of seven most typical bridge types used in Latvia from 1950 to 1990 (see Table 1). For data to be comparable, from the data set, there are excluded all renovated/reconstructed bridges, bridges with unique design and bridges which are built from other structural materials. It means that the typically analyzed bridge is built 30-70 years ago from prefabricated concrete elements without any repairs in its lifetime. In Figure 2, there is shown one of the typical bridge cross-sections - precast beams type 56.

Table 1. Analyzed bridge types

\begin{tabular}{|c|c|c|}
\hline Type of bridge span & Construction year & Amount \\
\hline Precast beams, type 56 (with diaphragms) & $50-60$ ties & 50 \\
\hline Precast plates (6m long) & $50-70$ ties & 48 \\
\hline Precast stringed concrete beams (with diaphragms) & 60 ties & 27 \\
\hline Precast beams, type 56 (without diaphragms) & $60-80$ ties & 86 \\
\hline Precast stringed concrete beams (without diaphragms) & 70 ties & 30 \\
\hline Precast hollow section plates & $70-90$ ties & 49 \\
\hline Precast trapezoid section beams & $80-90$ ties & 11 \\
\hline \multicolumn{2}{|l|}{ Total: } & $301(70 \%)$ \\
\hline \multicolumn{2}{|l|}{ Another construction* } & $130(30 \%)$ \\
\hline
\end{tabular}

* - renovated/reconstructed or another type of bridges (steel, masonry, wood, in-situ cast concrete etc.). 

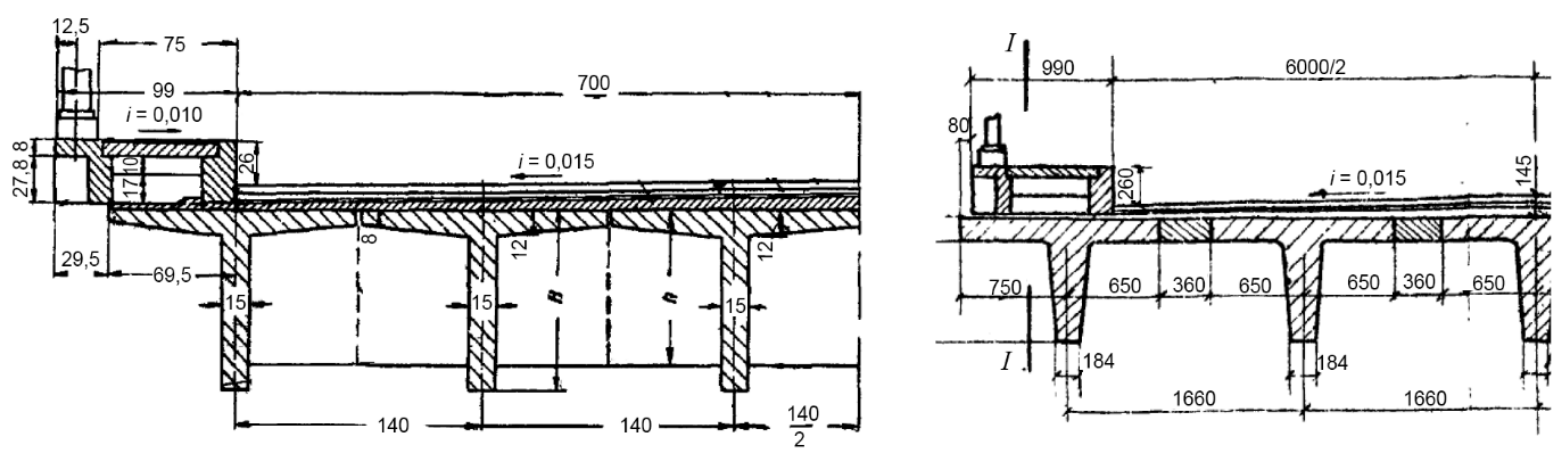

Figure 2. Typical precast beam (type 56) drawings (to the left with, to the right without diaphragms)

The distribution of the number of bridges by construction years is shown in Figure 3. Most of the bridges (80\%) on local roads are built from 1950 to 1990 ties. Older bridges are quite different from each other's, mostly build from reinforced concrete and are cast in place structures. Bridges constructed after 1990 are mostly cast-in-situ concrete structures.

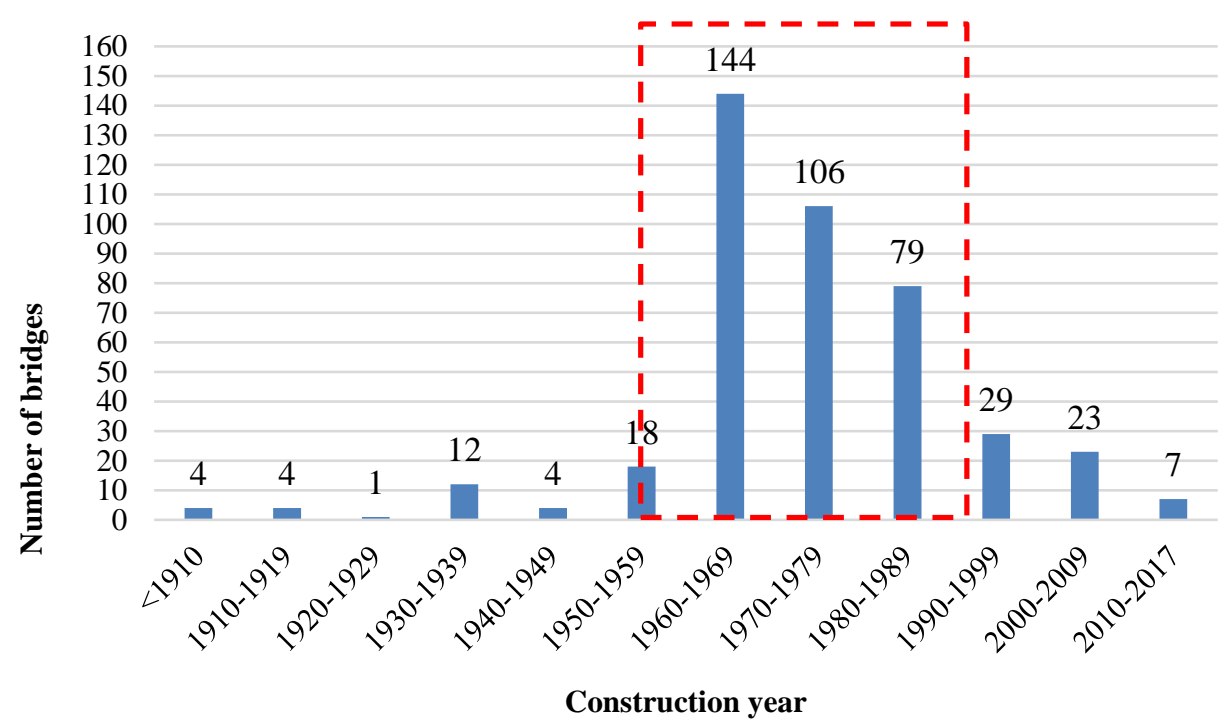

Figure 3. Bridge distribution by construction years

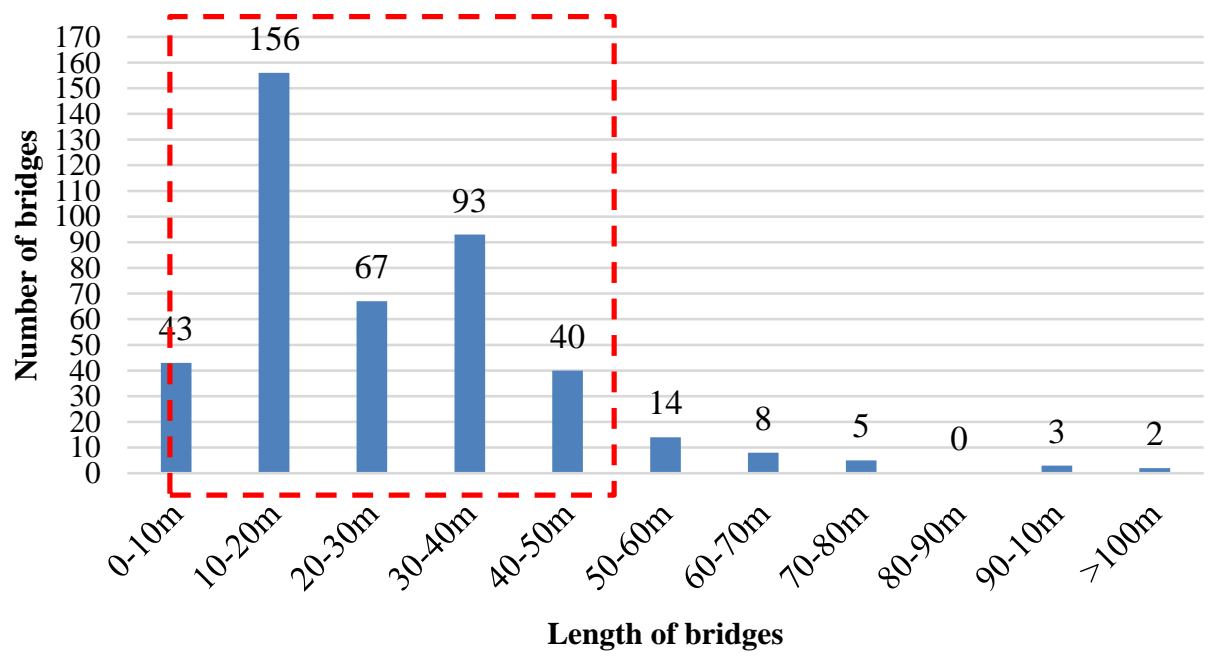

Figure 4. Bridge distribution by bridge length 
Bridges located on local roads mostly are with small and medium span length, from 2 to 50 meters (see Figure 4). The span length applied from a standardized bridge project. In standardized bridge projects span length varies from 6 to 24 meters and are used in one till three-span structures.

\section{Bridge management in Latvia}

The bridge management includes a wide range of activities from design and construction to replacement and is aimed to ensuring the safety and functionality throughout the lifetime of bridges. General scheme of bridge management in Latvia is shown in Figure 5. Since the data for this study will be derived from BMS, further is described the Latvian BMS LatBrutus inspection module.

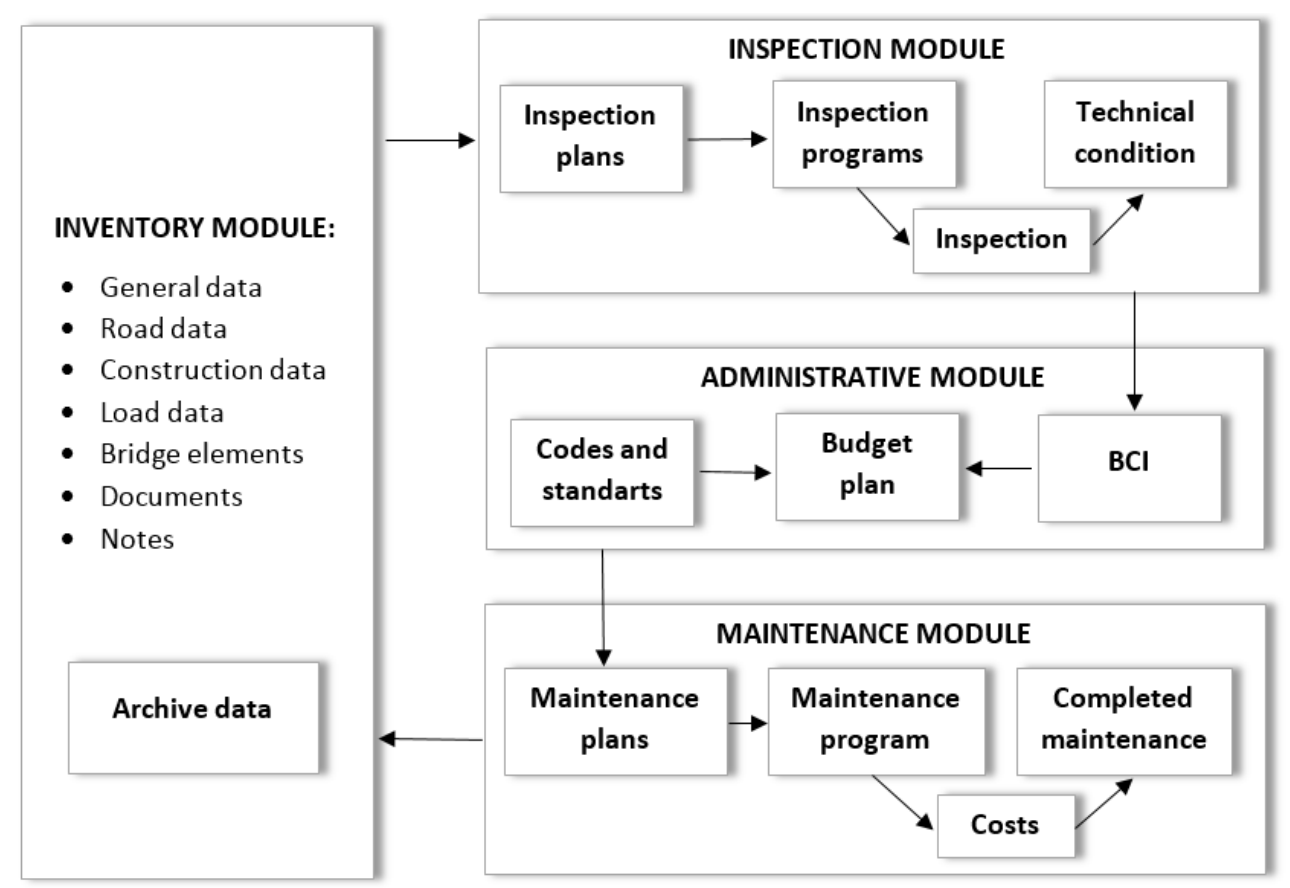

Figure 5. General scheme of Latvian bridge management system LatBrutus

\subsection{Inspection module}

Inspection module collects all data obtained by inspections during bridge lifetime. All inspections are done according to Latvian standard LVS 190-11 "Bridge inspection and load testing" (LVS 1.-1., 2009) there are provided such inspection types:

- Acceptance inspection - is carried out once, after the completing of a new bridge (birth certificate). The purpose is to accept or not the acceptance criteria for new bridge. Inspection shall also be performed after major rehabilitation or maintenance works.

- Warranty inspection - is carried out during the warranty period. The purpose is to check the quality of construction work before the end of the warranty period.

- General inspection - is carried out once a year. The purpose is to determine serious damages affecting load carrying capacity, traffic safety, increasing maintenance expenses, or influence the aesthetic appearance of the structure.

- Major inspection - is carried out once in a five year. The purpose is to determine any serious damage affecting load carrying capacity, traffic safety and functionality of bridge structures, as well the cost of necessary maintenance or intervention works. This inspection also includes measurements and materials investigation if necessary.

- Special inspection - is in-deep inspection, including assessment of load-carrying capacity. This is the nonregular inspection and will be performed when appropriate. The purpose of the inspection is detailed investigation damages and its causes observed in previous inspections or after bridge accidents, overloading, floods, or other reason.

Each observed damage, fault or defect recognized in the major inspection should be recorded and evaluated to clarify how such damage or fault could affect the individual bridge element, bridge as a whole or users of the bridge. In most cases, the evaluation of damage consists of visual assessment; however, in some cases measurements and 
material investigations are necessary. Damages should be described according to damage types listed in "Inspection Handbook". Any damage shall be assessed by considering the degree and consequence of damage. Evaluation of damages is based on inspector professional judgement and experience. If damage could influence the load-carrying capacity, then the careful static calculation should be performed before establishing the damage degree.

The degree of damage shall be evaluated in such a numerical scale:

1 - Minimal damage/defect - actions are not required

2 - Average damage/defect - actions are required in time of 4-10 years

3 - Serious damages/defects - actions are required in time of 1-3 years

4 - Critical damages/defects - urgent actions are required in terms till 1/2 year.

The damage types are codified. The most common damages are divided in 8 groups:

1 Group - Damage typical to the ground (codes from 101 to 119)

2 Group - Concrete element damages (codes from 201 to 290)

3 Group - Steel element damages (codes from 301 to 390)

4 Group - Masonry damages (codes from 401 to 490)

5 Group - Wood element damages (codes from 501 to 590)

6 Group - Pavement damages (codes from 601 to 690)

7 Group - Bearing and deformation joint damages (codes from 701 to 790)

8 Group - Drainage, road approaches and equipment damages (codes from 801 to 990).

Each type of damage is marked with three-digit code, where the first digit indicated the material or element, the second and the third indicate the type of damage. For example, code 212 - means delamination of the concrete element.

The consequences of damage indicated - what will be affected if the damage is not averted or repaired in time, and is marked with letters:

C - damage affect the load-carrying capacity

$\mathrm{T}$ - damage affect traffic safety

$\mathrm{M}$ - damage can affect maintenance costs

$\mathrm{E}$ - damage can influence the environment and aesthetics.

These effects are presented in prioritized order. This means that the damage that affects load carrying capacity will be given with higher priority. For example, designation 3C means - serious damage which can reduce the loadcarrying capacity of the structure if no repair is carried out within the next 1-3 years.

By using the evaluation of degree, consequence and type of damage can be calculated Bridge Condition Index (BCI). The calculation of Bridge Condition Index is based on different Damage Indexes (DI) multiplied by impact factor $(\mathrm{F})$. The Bridge Condition Index indicates the technical condition of the bridge and allows to follow the changes in time.

$$
\mathrm{BCI}=\sum\left(\mathrm{DI}_{1} \cdot \mathrm{F}_{1}+\mathrm{DI}_{2} \cdot \mathrm{F}_{2}+\ldots+\mathrm{DI}_{\mathrm{n}} \cdot \mathrm{F}_{\mathrm{n}}\right) .
$$

The Damage Index consists of factor $F_{D C}$ that include characteristics of damage degree and consequences, and factor $F_{\text {type }}$ that include code of the type of damage.

$$
\mathrm{DI}=\mathrm{F}_{\mathrm{DC}} \cdot \mathrm{F}_{\text {type }}
$$

Average weighted Bridge Condition Index $\left(B C I_{\text {average }}\right)$ that characterize the condition of stock of bridges within the region and could be obtained by:

$$
B C I_{\text {average }}=\sqrt{\frac{\sum\left(B C I_{1} \cdot L_{1}+B C I_{2} \cdot L_{2}+\ldots+B C I_{n} \cdot L_{n}\right)}{\sum\left(L_{1}+L_{2}+\ldots+L_{n}\right)}},
$$

where $L_{n}$ number of bridges.

\section{Analysis of the bridge condition according to LatBrutus data}

Data set of selected local road network bridges are analyzed according to the methodology provided by the bridge management system LatBrutus. In the database, the inspections data are available from 2002. During study for each bridge was analyzed three inspection cycles $(n, n+5, n+10)$, for example, inspection data from 2007, 2012 and 2017.

From the available 128 damage descriptions, five most characteristic defects of concrete bridge spans are selected (see Table 2). They characterized defects beginning with a poor design to the destructive environment and traffic impact. A coefficients $F_{\text {type }}$ is used for evaluation of each damage significance. The same is done for the bridge pavement damages (see Table 3). 
Table 2. Concrete element damages

\begin{tabular}{|c|l|c|}
\hline Code & \multicolumn{1}{|c|}{ Damage description } & F type \\
\hline 203 & Deformations of a concrete element & 3.50 \\
\hline 204 & Cracks in concrete element & 2.50 \\
\hline 209 & Insufficient or defective concrete cover & 1.50 \\
\hline 213 & Crumbling of a concrete element & 1.50 \\
\hline 214 & Corrosion of reinforcement & 3.00 \\
\hline
\end{tabular}

Table 3. Pavement damages

\begin{tabular}{|c|l|c|}
\hline Code & \multicolumn{1}{|c|}{ Damage description } & $\mathrm{F}_{\text {type }}$ \\
\hline 602 & Leakage in deck waterproofing & 2.50 \\
\hline 605 & Cracks and holes in the pavement & 2.00 \\
\hline 714 & Leakage in deformation joints & 2.50 \\
\hline 801 & Damaged drainage system & 2.00 \\
\hline
\end{tabular}

According to LatBrutus offered methodology, the selected damage descriptions for three inspection cycles are obtained and recalculated to damage index DI. Factors for load-carrying capacity " $C$ ", maintenance costs " $M$ ", the damage that affects traffic safety "T", the damage that can influence the environment and aesthetics "E" is given in Table 4. In Figure 6 there are some examples of some bridge defects and appropriate rating.

Table 4. Factor $F_{D C}$ for combined code degree and consequence of damage

\begin{tabular}{|c|c|c|c|c|}
\hline & $\mathrm{C}$ & $\mathrm{T}$ & $\mathrm{M}$ & $\mathrm{E}$ \\
\hline 1 & 0.0799 & 0.0412 & 0.0239 & 0.0033 \\
\hline 2 & 0.2008 & 0.1022 & 0.0651 & 0.0066 \\
\hline 3 & 0.3903 & 0.1876 & 0.1261 & 0.0083 \\
\hline 4 & 0.927 & 0.3068 & 0.2115 & 0.0333 \\
\hline
\end{tabular}

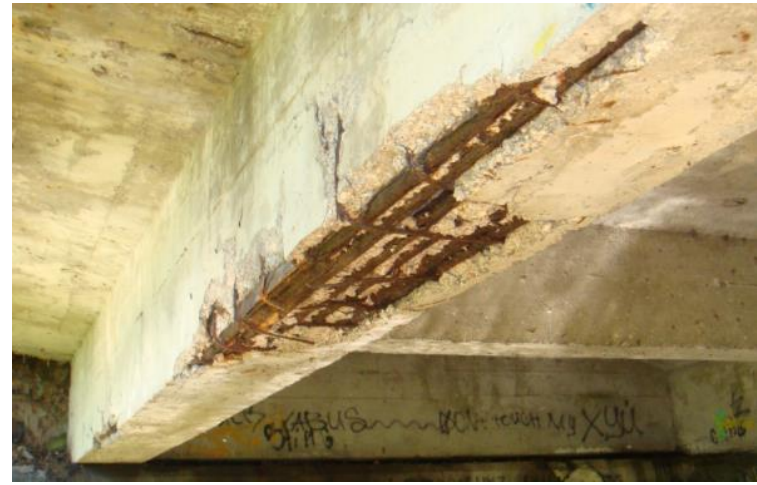

214/3C

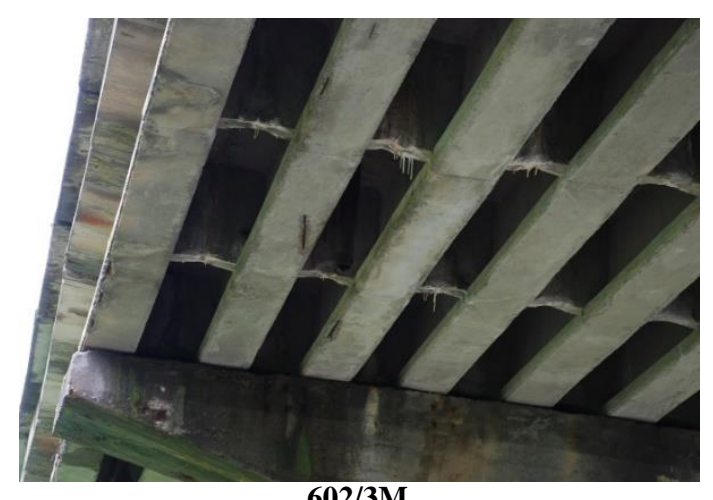

$602 / 3 M$

Figure 6. Examples for damage designation for concrete beam and pavement damage according LatBrutus methodology

\section{Results}

As a result, is obtained damage index (DI) for each concrete span damage type. The damage index is calculated for each major inspection year. The obtained results are presented in tables and spider diagrams in Figure 7 to Figure 13. With the red line are shown results of the first period of inspection, blue line - the next five year inspection period and the green line showed results of the next five year period. Spider diagrams showed the development of damages during inspection periods. Here we can see the speed of damage development. Proposed type of analysis and presentation of the results is useful for the evaluation of further bridge maintenance plans. The obtained results will be used for calculation of the overall bridge condition index (BCI) and the evaluation of the weight of each damage separately.

The results of the study showed that the major problem of the precast bridge types, mostly used on local roads, is the insufficient concrete cover layer that leads to corrosion of reinforcement and reduction of load-bearing capacity. The study showed that bridges built in 50ties are much more deteriorated compare to later structures. The most serious 
damages are obtained on precast beams, type 56 (with diaphragms), precast plates $(6 \mathrm{~m}$ long) and precast prestressed concrete beam span structures. Other bridge types, regarding concrete span defects, were in better condition.

\begin{tabular}{|l|c|c|c|}
\hline \multirow{2}{*}{ Damage code and description } & \multicolumn{3}{|c|}{ Inspection period } \\
\cline { 2 - 4 } & $\mathbf{n}$ & $\mathbf{n + 5}$ & $\mathbf{n + 1 0}$ \\
\hline 203 Deformation of concrete elements & 0 & 0 & 0 \\
\hline 204 Cracks in concrete element & 0.19975 & $\begin{array}{c}0.2602 \\
(+30 \%)\end{array}$ & $\begin{array}{c}0.3811 \\
(+46 \%)\end{array}$ \\
\hline 209 Insufficient concrete cover & 0.22866 & $\begin{array}{c}0.26493 \\
(+15 \%)\end{array}$ & $\begin{array}{c}0.35805 \\
(35 \%)\end{array}$ \\
\hline 213 Crumbling of concrete element & 0.09588 & $\begin{array}{c}0.16842 \\
(+75 \%)\end{array}$ & $\begin{array}{c}0.22866 \\
(+35 \%)\end{array}$ \\
\hline 214 Corrosion of reinforcement & 0.14382 & $\begin{array}{c}0.2643 \\
(+83 \%)\end{array}$ & $\begin{array}{c}0.40938 \\
(+54 \%)\end{array}$ \\
\hline
\end{tabular}

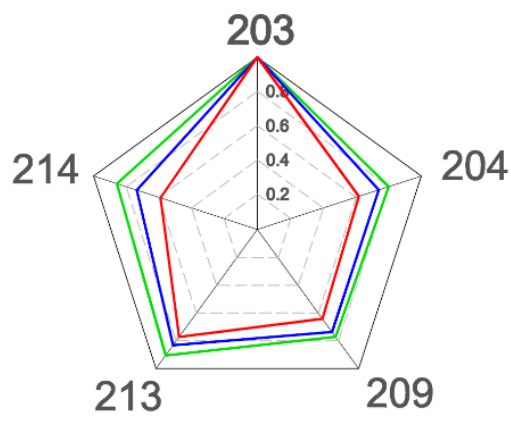

Figure 7. Precast beams, type 56 (with diaphragms)

\begin{tabular}{|l|c|c|c|}
\hline \multicolumn{1}{|c|}{ Damage code and description } & \multicolumn{3}{|c|}{ Inspection period } \\
\cline { 2 - 4 } & $\mathbf{n}$ & $\mathbf{n + 5}$ & $\mathbf{n + 1 0}$ \\
\hline 203 Deformation of concrete elements & 0.16779 & $\begin{array}{c}0.22372 \\
(+33 \%)\end{array}$ & $\begin{array}{c}0.44891 \\
(+100 \%)\end{array}$ \\
\hline 204 Cracks in concrete element & 0.2602 & $\begin{array}{c}0.32065 \\
(+23 \%)\end{array}$ & $\begin{array}{c}0.3811 \\
(+18 \%)\end{array}$ \\
\hline 209 Insufficient concrete cover & 0.35805 & $\begin{array}{c}0.4149 \\
(+16 \%)\end{array}$ & $\begin{array}{c}0.5286 \\
(+27 \%)\end{array}$ \\
\hline 213 Crumbling of concrete element & 0.19239 & $\begin{array}{c}0.26493 \\
(+37 \%)\end{array}$ & $\begin{array}{c}0.4149 \\
(+56 \%)\end{array}$ \\
\hline 214 Corrosion of reinforcement & 0.45732 & $\begin{array}{c}0.64356 \\
(+40 \%)\end{array}$ & $\begin{array}{c}0.9435 \\
(+46 \%)\end{array}$ \\
\hline
\end{tabular}

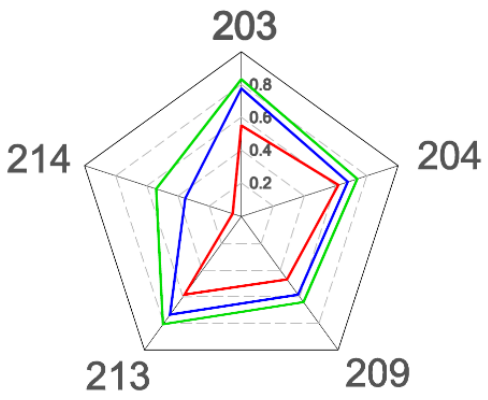

Figure 8. Precast plates (6 m long)

\begin{tabular}{|l|c|c|c|}
\hline \multicolumn{1}{|c|}{ Damage code and description } & \multicolumn{3}{|c|}{ Inspection period } \\
\cline { 2 - 4 } & $\mathbf{n}$ & $\mathbf{n + 5}$ & $\mathbf{n + 1 0}$ \\
\hline 203 Deformation of concrete elements & 0.139825 & $\begin{array}{c}0.11186 \\
(0 \%)\end{array}$ & $\begin{array}{c}0.11186 \\
(0 \%)\end{array}$ \\
\hline 204 Cracks in concrete element & 0.19975 & $\begin{array}{c}0.19975 \\
(0 \%)\end{array}$ & $\begin{array}{c}0.32065 \\
(60 \%)\end{array}$ \\
\hline 209 Insufficient concrete cover & 0.19239 & $\begin{array}{c}0.26493 \\
(+37 \%)\end{array}$ & $\begin{array}{c}0.35805 \\
(+35 \%)\end{array}$ \\
\hline 213 Crumbling of concrete element & 0.11985 & $\begin{array}{c}0.22866 \\
(+90 \%)\end{array}$ & $\begin{array}{c}0.26493 \\
(+15 \%)\end{array}$ \\
\hline 214 Corrosion of reinforcement & 0.2397 & $\begin{array}{c}0.31224 \\
(30 \%)\end{array}$ & $\begin{array}{c}0.6024 \\
(92 \%)\end{array}$ \\
\hline
\end{tabular}

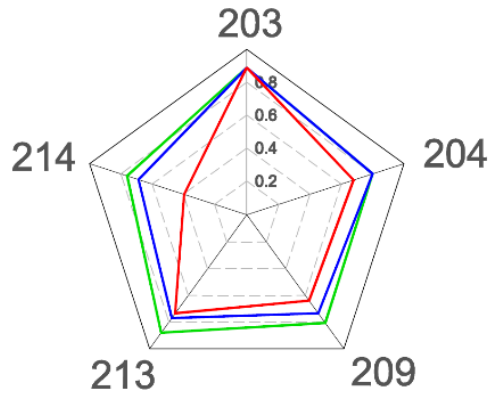

Figure 9. Precast stringed concrete beams (with diaphragms)

\begin{tabular}{|l|c|c|c|}
\hline \multicolumn{1}{|c|}{ Damage code and description } & \multicolumn{3}{|c|}{ Inspection period } \\
\cline { 2 - 4 } & $\mathbf{n}$ & $\mathbf{n + 5}$ & $\mathbf{n + 1 0}$ \\
\hline 203 Deformation of concrete elements & 0 & 0 & 0 \\
\hline 204 Cracks in concrete element & 0.03995 & $\begin{array}{c}0.03995 \\
(0 \%)\end{array}$ & $\begin{array}{c}0.11985 \\
(0 \%)\end{array}$ \\
\hline 209 Insufficient concrete cover & 0.11985 & $\begin{array}{c}0.15612 \\
(+30 \%)\end{array}$ & $\begin{array}{c}0.15612 \\
(0 \%)\end{array}$ \\
\hline 213 Crumbling of concrete element & 0.04794 & $\begin{array}{c}0.04794 \\
(0 \%)\end{array}$ & $\begin{array}{c}0.07191 \\
(+50 \%)\end{array}$ \\
\hline 214 Corrosion of reinforcement & 0.04794 & $\begin{array}{c}0.04794 \\
(0 \%)\end{array}$ & $\begin{array}{c}0.04794 \\
(0 \%)\end{array}$ \\
\hline
\end{tabular}

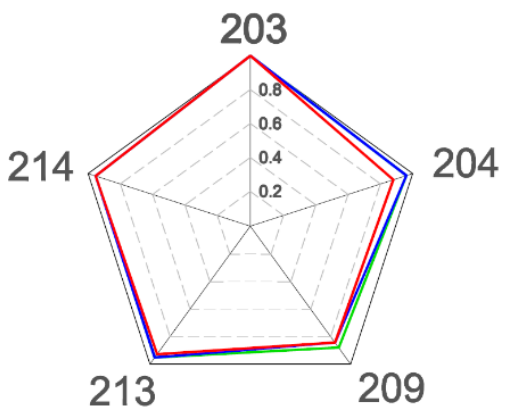

Figure 10. Precast concrete beams, type 56 (without diaphragms) 


\begin{tabular}{|l|c|c|c|}
\hline \multicolumn{1}{|c|}{ Damage code and description } & \multicolumn{3}{c|}{ Inspection period } \\
\cline { 2 - 4 } & $\mathbf{n}$ & $\mathbf{n + 5}$ & $\mathbf{n + 1 0}$ \\
\hline 203 Deformation of concrete elements & 0 & 0 & 0 \\
\hline 204 Cracks in concrete element & 0 & 0 & 0 \\
\hline 209 Insufficient concrete cover & 0.11985 & $\begin{array}{c}0.11985 \\
(0 \%)\end{array}$ & $\begin{array}{c}0.22866 \\
(+90 \%)\end{array}$ \\
\hline 213 Crumbling of concrete element & 0 & 0.04794 & $\begin{array}{c}0.04794 \\
(+0 \%)\end{array}$ \\
\hline 214 Corrosion of reinforcement & 0 & 0.04794 & $\begin{array}{c}0.09588 \\
(+20 \%)\end{array}$ \\
\hline
\end{tabular}

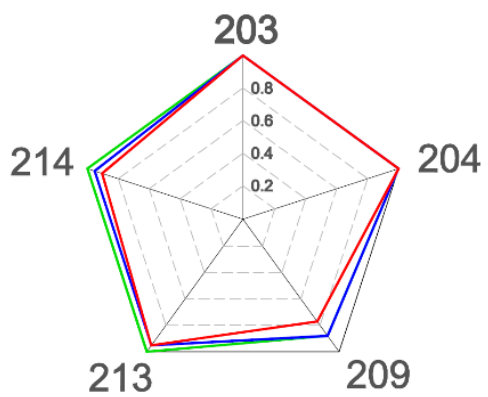

Figure 11. Precast stringed concrete beams (without diaphragms)

\begin{tabular}{|l|c|c|c|}
\hline \multicolumn{1}{|c|}{ Damage code and description } & \multicolumn{3}{c|}{ Inspection period } \\
\cline { 2 - 4 } & $\mathbf{n}$ & $\mathbf{n + 5}$ & $\mathbf{n + 1 0}$ \\
\hline 203 Deformation of concrete elements & 0 & 0 & 0 \\
\hline 204 Cracks in concrete element & 0 & 0.03995 & $\begin{array}{c}0.03995 \\
(0 \%)\end{array}$ \\
\hline 209 Insufficient concrete cover & 0.11985 & $\begin{array}{c}0.11985 \\
(0 \%)\end{array}$ & $\begin{array}{c}0.19239 \\
(+60 \%)\end{array}$ \\
\hline 213 Crumbling of concrete element & 0 & 0 & 0 \\
\hline 214 Corrosion of reinforcement & 0 & 0.04794 & $\begin{array}{c}0.09588 \\
(+20 \%)\end{array}$ \\
\hline
\end{tabular}

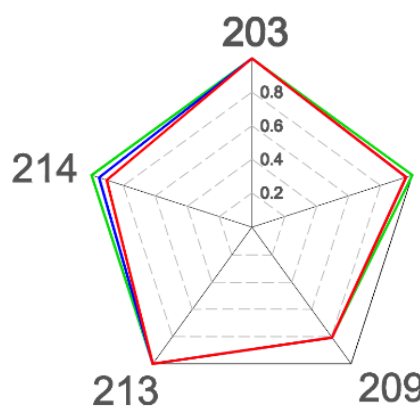

Figure 12. Precast hollow section plates

\begin{tabular}{|l|c|c|c|}
\hline \multirow{2}{*}{ Damage code and description } & \multicolumn{3}{c|}{ Inspection period } \\
\cline { 2 - 4 } & $\mathbf{n}$ & $\mathbf{n + 5}$ & $\mathbf{n + 1 0}$ \\
\hline 203 Deformation of concrete elements & 0.027965 & 0.027965 & 0.027965 \\
\hline 204 Cracks in concrete element & 0.019975 & 0.019975 & $\begin{array}{c}0.0799 \\
(400 \%)\end{array}$ \\
\hline 209 Insufficient concrete cover & 0.011985 & $\begin{array}{c}0.07191 \\
(+600 \%)\end{array}$ & $\begin{array}{c}0.144135 \\
(+200 \%)\end{array}$ \\
\hline 213 Crumbling of concrete element & 0 & 0.011985 & $\begin{array}{c}0.02397 \\
(+200 \%)\end{array}$ \\
\hline 214 Corrosion of reinforcement & 0 & 0.04794 & $\begin{array}{c}0.09588 \\
(+200 \%)\end{array}$ \\
\hline
\end{tabular}

Figure 13. Precast trapezoid section beams

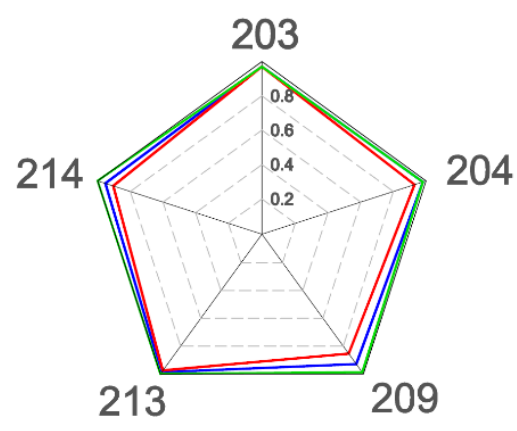

\section{Conclusions}

In this study are investigated bridge structures on local road network built between 1950 and 1989 when it was widely used prefabricated span structures in the form of reinforced concrete beams and plates constructed according to specific design model project albums. The study showed that precast reinforced concrete span structures have several shortcomings: low-quality joints; an incomplete waterproofing system that left outside beams uncovered; insufficient concrete coating thickness; lower-quality concrete that does not provide sufficient corrosion protection of reinforcement. For assessment of damage level in structures are used damage index DI method used in Latvian BMS "LatBrutus". Obtained results show that damage index DI for observed damage types increased from 0 to $600 \%$ during the two five-year inspection period. This points to the fact that reduced maintenance requirements and repairs, on the "residual fonds" principle, accelerate the development of damages and will require additional funds to prevent them in the future.

\section{References}

LVS, 1.-1. (2009). Tilta inspekcija un pārbaude ar slodzi. Riga: Latvijas Valsts standarts.

Mondoro, A, Frahgopol, D. M., Liu, L. (2018). Bridge adaptation and management under climate change uncertainties: A review. Natural Hazards Review, 19(1), 1-10. https://doi.org/10.1061/(ASCE)NH.1527-6996.0000270 
Quirk, L., Matos, J., Murphy, J., \& Pakrashi, V. (2018). Visual inspection and bridge management. Structure and Infrastructure Engineering, 14(3), 320-332. https://doi.org/10.1080/15732479.2017.1352000

Ryall, M. (2006). Bridge management. Elsevier Butterworth-Heineman. https://doi.org/10.1201/b12848

Rīkojums Nr. C/55 Par tiltu uzturēšanu un remontiem. (1938). Celšs un satiksme, 13, 2.

SNiP, 3.-8. (1987). Mosty i truby. Pravila obsledovanij i ispytanij. CITP Gosstroja SSSR.

Stensvold, B. (1997). Computer aided bridge management in Norway. Repair of concrete structures (pp. 545-553). Norvegian Road Research Laboratory.

VSN-81. (1981). Instukcija po provedeniju osmotrov mostov i trub na avtomobil'nyh dorogah. Transport. 